\title{
Comparative Analysis of the Health Status of the Population in Six Health Zones in South Kivu: a Cross-sectional Population Study Using the WHODAS
}

Samuel Makali Lwamushi ( $\square$ samuelmakali11@gmail.com )

Catholic University of Bukavu, school of public health https://orcid.org/0000-0003-3538-1715

Espoir Bwenge Malembaka

Catholic University of Bukavu, School of Public Health

Anne-Sophie Lambert

Université Catholique de Louvain, Institut de recherche santé et société

Hermès Karemere Bimana

Catholic University of Bukavu, school of public health

Christian Molima Eboma

Catholic University of Bukavu, school of public heath

Albert Tambwe Mwembo

Université de Lubumbashi, Ecole de santé publique

Steven Bames Ssali

Makerere University

Ghislain Bisimwa Balaluka

Catholic University of Bukavu, school of public health

Phillippe Donnen

Université Libre de Bruxelles, Ecole de santé publique

Jean Macq

Université Catholique de Louvain, Institut de recherche santé et société

Research

Keywords: Health status, population, WHODAS, Conflict, South Kivu, DRC

Posted Date: December 16th, 2020

DOI: https://doi.org/10.21203/rs.3.rs-127388/v1

License: (c) (7) This work is licensed under a Creative Commons Attribution 4.0 International License. Read Full License 


\section{Abstract}

Background: The eastern Democratic Republic of Congo (DRC) has experienced decades-long armed conflicts which might have had a negative impact on population's health. Most studies have used reductionist health measures such as morbidity and mortality rather than person-centered approaches for measuring the health status of the population. The aim of this study was to assess the health status of the population and its predictors in conflict settings of South Kivu province, using the World Health Organization Disability Assessment Schedule (WHODAS).

Methods: Between May and June 2019, we conducted a community-based cross-sectional survey among 1,440 adults in six health zones (HZ), classified according to their level of armed conflict intensity and chronicity in four types (accessible and stable, remote and stable, intermediate and unstable). The data were collected by a questionnaire including socio-demographic data and the WHODAS 2.0 tool with 12 items. The main variable of the study was the WHODAS summary score measuring individual's health status and synthesize in six domains of disability (household, cognitive, mobility, self-care, social and society). Univariate analysis, correlation and comparison tests as well as hierarchical multiple linear regression were performed.

Results: The median WHODAS score in the accessible and stable (AS), remote and stable (RS), intermediate (I) and unstable (U) HZ was 6.3 (0-28.6); 25 (6.341.7); 22.9 (12.5-33.3) and 39.6 (22.9-54.2), respectively. Four of the six WHODAS domain scores (household, cognitive, mobility and society) were the most altered in the UHZs. The RSHZ and IHZ had statistically comparable global WHODAS scores. The stable HZs (accessible and remote) had statistically lower scores than the UHZ on all items. In regression analysis, the factors significantly associated with an overall poor health status (or higher whodas score) were advanced age, being woman, being membership of an association; being divorced, separated or widower and living in an unstable $\mathrm{HZ}$.

Conclusions: Armed conflicts have a significantly negative impact on people's perceived health, particularly in crisis health zones. In this area, we must accentuate actions aiming to strengthen people's psychosocial well-being.

\section{Background}

Regions affected by armed conflict are far behind in achieving their development goals (1). Beyond death and physical trauma directly attributable to armed conflict, the resulting socio-political instability leads to a discontinuation of the provision of health services, the limitation of access to care and a dysregulation of health system governance (2-4). It also has an impact on the socio-economic life of people, the education of citizens and contributes to the impoverishment of communities (5-9).

All these factors create conditions that interfere with strategies for control and response to communicable diseases. Protracted conflict is also associated with food insecurity and high maternal and child morbidity and mortality (3), and ultimately affects the health status of the general population (10, 11).

The Democratic Republic of Congo (DRC) has been at the heart of repeated armed conflicts for several years. The main conflicts, including the 1996's described as "world war for Africa"(12), took place mainly in the eastern part of the country (particularly in the provinces of Ituri, North Kivu and South Kivu). As a result of these conflicts, the national crude death rate rose from 1.3 deaths per 1,000 population per month in 1997 to 2.2 deaths per 1,000 population per month in 2002 (13). This rate would exceed by $40 \%$ (for the whole country) and 60\% (in the East of the country) the African average in 2013 (14).

Since 1993, an estimated 4.1 million people have been internally displaced in the east of the country (15). At the same time, there has been a proliferation of armed groups in this region. According to the Human Right Watch report, more than 140 armed groups are active in North and South Kivu (16).

Armed conflicts have weakened the health system, affecting both health personnel and health facilities. For example, there have been a total of 96 incidents targeting the health system in South Kivu between April 2017 and October 2019 (17). Another striking fact is the outbreak of armed conflict in Bijombo (Uvira, South Kivu) which has resulted in nearly 3,500 internally displaced persons (IDPs). In this region, the general referral hospital and eight other health facilities were closed, depriving nearly 60,000 people of health care in 2018 (18).

Some authors assumed that humanitarian aid focused on vertical programs is one of the means to maintain the performance of the health system in conflict situations (19). In South Kivu, at the end of January 2018, there were almost 36 humanitarian actors working on 51 ongoing projects (20). Nevertheless, several indicators of population health remain generally worrying in South Kivu. It has one of the highest prevalence of stunting in children under 5 years old (53\%) (21) and the highest infant mortality rate in the country (92\%o) (22).

In DRC, the health status of a population is often assessed using health indicators that reflect disease-related mortality and/or morbidity(23). This way of measuring health status does not consider other aspects of the person (social, psychological) that seem to have a significant impact on that person's health, especially in crisis situations related to armed conflict.

Despite the growing recognition in the global literature of the deleterious effects of armed conflict on health systems, few studies have assessed health status at the community level in the provinces of Kivu. The existing study, which used World Health Organization Disability Assessment Schedule (WHODAS), have focused on specific populations (24), without rigorously assessing the real impact of crises linked to armed conflict on communities' health. Also, in most studies on the health status of a population, the focus is usually on measures focused on deaths or specific health problems.

This study assessed the health status of people in health zones of South Kivu with different socio-political and security profiles. We used the World Health Organization Disability Assessment Schedule (WHODAS) to measure the health status of the population and its associated factors, from a person-centered rather than a disease-centered perspective.

\section{Methods}




\section{Study design and setting}

We conducted a community-based cross-sectional and household survey from May to June 2019.

This study was carried out in South Kivu, one of the eastern provinces of DR Congo. This province has one capital city (Bukavu) and eight territories. Its population is estimated at 6,937,726 inhabitants in 2018 (three quarters of whom live in rural areas), applying a growth rate of 1.03 per year to the population enumerated in 2012 , distributed over $64,791 \mathrm{Km}^{2}(25)$. In terms of healthcare services governance, the province has two levels: the provincial health division is composed of several health programs, and supports the health zone. Each health zone has a network of primary and secondary level health facilities centered around a referral hospital (14). Among the 34 health zones (HZs) of the South-Kivu provinces, six were selected, of which five were rural (Mulungu, Fizi, Walungu, Bunyakiri and Idjwi) and one urban (Kadutu). The selection of these health zones was made arbitrarily, considering their socio-demographic differences and security settings.

The Kadutu $\mathrm{HZ}$ is a mixed zone (urban and peri-urban) without large-scale armed conflicts for more than 5 years. Idjwi Island is a rural $\mathrm{HZ}$ that has been protected from the direct effects of armed conflict in eastern DR Congo, due to its geographic location. The other four HZs (Bunyakiri, Walungu, Mulungu et Fizi) are rural and have different profiles regarding armed conflict and international aid.

\section{Typology of Health zones}

The armed conflict level was defined for each $\mathrm{HZ}$ by using two parameters: the number of deaths directly related to armed conflict (BRD) and the number of internally displaced persons (IDPs).

For the first parameter, we used the raw data on deaths attributable to armed conflict. This was extracted from the Uppsala Conflict Data Program Battlerelated Deaths Dataset (UCDP BRD) database from 2013 to 2018 (26-28). This database has several variables including the type of conflict, the location of the conflict (up to the level of territories of a province) as well as the geolocation data of the conflict from 1989 to 2018 . Created for research purposes, UCDP BRD defined deaths related to armed conflict as "deaths caused by warring parties that may be directly related to battle" (28). This data base seemed to be more complete for our study than others such as the ACLED (Armed Conflict Location Events Dataset) $(29,30)$. Health zones mapping data was obtained through shapefile downloaded from the United Nations Office for the Coordination of Humanitarian Affairs (UNOCHA) database (31). We then merged the HZ mapping and BRD data with Quantum Geographic Information System (QGIS) software which allowed us to put each BRD in its HZ. The BRD was obtained by dividing the total number of deaths related to armed conflicts from 2013-2018 by the average of the population from 2013 to 2018 . Thus, the BRDs were 2.4, $51.7,0.4,0,21$ and 0.4 (per 100,000 inhabitants) respectively for the Bunyakiri, Fizi, Idjwi, Kadutu, Mulungu and Walungu HZs. A HZ with had more than 5 BRD per 100,000 inhabitants was considered to be in conflict (32).

For the second parameter, we used UNOCHA data on IDPs for the South Kivu territories in which the HZs were located. The data available were those for 2014 and $2017(33,34)$. We used the 1998 OCHA guideline to define IDPs (35). Thus, the number of IDPs during the two years was 434,014; 244,798; 6,600; 2,755; 16,7010 and 47,965 respectively in the territories of Kalehe (Bunyakiri HZ), Fizi (Fizi HZ), Idjwi (Idjwi HZ), City of Bukavu (Kadutu HZ), Shabunda (Mulungu HZ) and Walungu (Walungu HZ). An arbitrary threshold of over 50,000 IDPs was considered suggestive of a conflict $\mathrm{HZ}$.

With the two parameters, and to other similar studies $(11,32)$, we obtained three types of health zones according to their level of crisis. Kadutu, Idjwi and Walungu were classified as "stable HZs" (those with less than 5BRD from 2013 to 2018 and who registered less than 50,000 IDPs during the years 2014 and 2017). This class was split into two groups to highlight the

feature of the Idjwi HZ. Kadutu and Walungu HZs were ultimately considered to be "accessible and stable HZ" (AS) and Idjwi as "remote and stable HZ" (RS). Bunyakiri was classified as an "intermediate $(\mathrm{I}) \mathrm{HZ}$ " because the territory in which this $\mathrm{HZ}$ is located had less than 5BRD in the five years but had more than 50,000 IDPs. Finally, the Fizi and Mulungu HZs were considered as "unstable (U) HZ" because they had more than 5BRD from 2013 to 2018 and were located in a territory with more than 50,000 IDPs.

\section{Study size}

Using the Stata 15 sample calculation package for analysis of variance, considering an intergroup variance of 393 as observed in a recent study in South Kivu (24), and the mean values of WHODAS of 8.2, 10.2 and 12.2 for the conflicting, intermediate and stable areas respectively, and assuming a type 1 error of $5 \%$ with a power of $80 \%$, the minimum sample size required was 1425 participants. And so, we collected data from 48 people per village, or 240 people per health zone, which gave us a total of 1,440 participants.

\section{Selection of participants and sampling procedure}

The population of this study was made up of people aged 18 or over, residing in the health zone for more than one year. Multi-level sampling was carried out. At the first stage, five health areas were randomly selected from each $\mathrm{HZ}$. Within each health area, 48 households were then randomly selected. Three of the selected health areas (two in Mulungu and one in Bunyakiri) were not accessible due to accessibility and insecurity issues. They were replaced by three neighboring health areas which were more accessible. In each health area, the list of households was obtained from the village chief. From a central point represented by a church, we choose the direction (using direction indicated by the tip of a discarded pen) in which the households to be surveyed were randomly selected. Within each household, the adult who was found there during a first visit was interviewed. In the household where there was no adult on this visit, a second visit was executed in the afternoon.

Excluded were all those with severely impaired mental health who were not able to provide an informed consent.

Data collection

Page $3 / 12$ 
A structured and pre-tested questionnaire was used to collect socio-demographic and economic data from the participants. WHODAS, originally in English, has been translated into Kiswahili and French by the team of linguists from the School of Languages at the Catholic University of Bukavu, following the WHO principle of translation and back-translation. Data collection was done by six doctors trained in observing ethical principles, confidentiality and nonmaleficence, and also on the correct use of WHODAS.

\section{Variables, instrument and measurements}

The main variable of the study is the WHODAS summary score measuring an individual's health status. The WHODAS score ranges from 0 to 48 , measuring the cognitive, functional and social performance of the participants; the lower the score the better the health status. We converted this score into a percentage (varying from 0 to 100) to make the comparison and interpretation easy.

The WHODAS (with 12 items) is a standardized WHO questionnaire with good psychometric properties (36, 37), adapted to several cultures and validated in several countries (38), including among children in rural areas of middle and low income countries (39). In a recent study, it was shown that WHODAS can be used to measure the health status of populations in rural and semi-urban areas of South Kivu (24).

WHODAS items, each scored from 0 to 4 , were condensed into six groups summarizing the six domains of disability (assisting and completing daily tasks, acquiring and using information, moving and handling objects, taking care of self, interacting with others and participating in society). This choice comes from a principal component analysis carried out by Andrews, who showed that the grouping of the twelve WHODAS items in these six domains was the best model for measuring overall health status (40).

The socio-cultural and demographic characteristics as well as the type of the $\mathrm{HZ}$ of residence were analyzed as explanatory variables. We defined the socioeconomic status of the respondents according to the procedure developed by Filmer and Pritchett (41) based on the possession of durable household assets and used in demographic and health surveys. The socio-demographic status was therefore obtained thanks to a multiple correspondence analysis grouping together 14 sub-variables and thus defining three classes (low, medium and high). The variable « membership of a local saving association » brought together people who were part of any development association in the community.

\section{Data management and statistical methods}

The data was encoded in Epi Info 7 and exported to Excel for cleaning. The analysis was performed with IBM SPSS version 25 software. The frequencies with proportions and medians with interquartile ranges were used respectively to summarize the qualitative and quantitative variables. We used the Box-Cox transformation to normalize our dependent variable, the WHODAS score. Chi-square test was used to compare categorical variables while nonparametric tests (Kruskall-Wallis and Wilcoxon with Bonferroni adjustment) were used to compare quantitative variables, including WHODAS score. The Z-test, with Bonferroni adjustment, was used to compare the characteristics of the population and the types of health zones. A hierarchical linear regression was performed to examine the contribution of each factor to the explanation of the variance of the WHODAS score. We test two models: the first representing only the sociodemographic characteristics of the participants and the second incorporating the level of crisis (or the type of health zone) into the first model. There was no multicollinearity problem because all of the variance inflation factor (VIF) values were $<1.5$. Only the variables having a $p$-value $<0.05$ in the analyzes of variance with one factor (ANOVA with 1 factor) or of correlation test of Pearson were introduced in the models. We finally choose the model which has a lower AIC (Akaike information criteria).

\section{Results}

\section{Characteristics of the population and their distribution in types of health zones}

The median age and the gender distribution of respondents were identical in all types of HZs. The Shi and Havu tribe were more common in stable health zones. The proportion of Catholics and formal employees was higher in AS HZs. The major occupation in other HZs was conducting small business as compared to the AS HZ. Temporary housing and medium socio-economic level characterize the population living in UHZs. Development associations were more common in the RS HZ.

\section{WHODAS score by health zone types}

The median (Interquartile range) [med (IQR)] overall score of the participants was 25,0 (6.3-41.7). Only the score obtained by the IHZ and RS HZ were not statistically different. The UHZs have the highest score. By comparing them two by two we notice that: (1) the IHZ has at least one similar item with each of the three other types of $\mathrm{HZ}$; (2) The stable $\mathrm{HZ}$ (accessible and remote) have markedly different scores from those of the UHZ on almost all items; (3) the AS and IHZs have in common the item concerning participation in the life of society (society); the IHZ and UHZ have in common the item of taking care of oneself (Self-care). The RS and IHZ have in common the items concerning cognitive aspects and interaction with other members of the community (Cognitive and Social). 
Table 1

Sociocultural and demographic characteristics and univariate analysis by types of health zones $(\mathrm{n}=1440)$

\begin{tabular}{|c|c|c|c|c|c|}
\hline Variables & $\begin{array}{l}\text { Accessible } \\
\text { and } \\
\text { stable (AS) }\end{array}$ & $\begin{array}{l}\text { Remote } \\
\text { and } \\
\text { stable (RS) }\end{array}$ & $\begin{array}{l}\text { Intermediate } \\
(I)\end{array}$ & $\begin{array}{l}\text { Unstable } \\
\text { (U) }\end{array}$ & $\mathbf{p}(*)(* *)$ \\
\hline Age unités? & $38(25-52)$ & $32(25-42)$ & $31(23-46)$ & $37(26-53)$ & $p(I / L E)=1$ et $p(R S / C)=1$ \\
\hline \multicolumn{6}{|l|}{ Sex } \\
\hline Male & 195(40.7) & $100(42.0)$ & $92(38.3)$ & $211(44)$ & $p=0.52$ décimales? \\
\hline Female & $284(59.3)$ & $138(5.08)$ & $148(61.7)$ & $269(56)$ & $P=0.5$ \\
\hline \multicolumn{6}{|l|}{ Marital statues } \\
\hline Never married & $112(23.4)$ & 33(13.8) & $39(16.4)$ & $96(20)$ & $p(R S / L E)=0.01$ \\
\hline Married & $308(64.4)$ & $174(72.5)$ & $162(68.1)$ & $308(64.2)$ & $p>0.05$ \\
\hline Separated or divorced & $8(1,7)$ & $7(2.9)$ & $17(7.1)$ & $29(6)$ & $p(l ; C / R S)=0.001 / 0.003$ \\
\hline Widower & $50(10.5)$ & $26(10.8)$ & $20(8.4)$ & $47(9.8)$ & $p>0.05$ \\
\hline \multicolumn{6}{|l|}{ Tribe } \\
\hline Shi and Havu & $396(82.7)$ & $155(65.1)$ & $27(11.3)$ & $6(1.3)$ & $p(R S ; L E / C ; I)=<0.001$ \\
\hline Rega & $27(5.6)$ & $1(0.4)$ & $35(14.6)$ & $236(49.5)$ & $p(C ; I / R S ; L E)=<0.001$ \\
\hline Bembe & $0(0)$ & $0(0)$ & $0(0)$ & $114(23.9)$ & / \\
\hline Tembo & $1(0.2)$ & $0(0)$ & $58(24.3)$ & $0(0)$ & $p(I / R S)=<0.001$ \\
\hline Others & $55(11.5)$ & $121(25.4)$ & $119(49.8)$ & $121(25.4)$ & $p(I / R S ; L E ; C)=<0.001$ \\
\hline \multicolumn{6}{|l|}{ Religion } \\
\hline Catholic & $306(63.7)$ & $81(34)$ & $73(30.4)$ & 161(33.6) & $p(R S / L E ;, ; C)=<0.001$ \\
\hline Protestant & $158(32.9)$ & $141(59.8)$ & $123(51.2)$ & $253(52.8)$ & $p(L E, ; / C / R S)=<0.001$ \\
\hline Muslim & $10(2.1)$ & $0(0)$ & $7(2.9)$ & $43(9)$ & $p(C / R S ; I)=<0.001 / 0.008$ \\
\hline Others & $6(1.3)$ & $16(6.7)$ & $37(15.4)$ & $22(4.6)$ & $\begin{array}{l}p(L E ;, ; C / R S)=<0.001 \text { and } p(I / L E ; C)= \\
<0.001 / 0.15\end{array}$ \\
\hline \multicolumn{6}{|l|}{ Respondent's occupation } \\
\hline Formal employee & $76(15.9)$ & $11(4.6)$ & $23(9.6)$ & $35(7.3)$ & $p(R S / L E ; C)=<0.001$ \\
\hline Occasional work & $0(0)$ & $0(0)$ & $1(0.4)$ & 18(3.8) & $p(C / I)=0.009$ \\
\hline Small business & 104(21.7) & $131(54.8)$ & $126(52.7)$ & $278(58)$ & $p(L E ; / ; C / R S)=<0.001$ \\
\hline Farmer & $54(11.3)$ & $40(16.7)$ & $17(7.1)$ & $51(10.6)$ & $p(L E / I)=0.007$ \\
\hline Unemployed & $245(51.1)$ & $57(23.8)$ & $72(30.1)$ & $97(20.3)$ & $p(S A / L E ; / ; C)=<0.001$ and $p(I / C)=0.02$ \\
\hline Number of adults in the household & $4(2-5)$ & $2(2-3)$ & $3(2-4)$ & $3(2-4)$ & $P(S E / C)=0.29$ and $p(C / I)=0.42$ \\
\hline \multicolumn{6}{|l|}{ Type of housing } \\
\hline Temporary & $232(48.3)$ & $112(46.9)$ & $125(52.1)$ & 294(61.4) & $P(C / R S ; L E)=<0.001 / 0.001$ \\
\hline Semi-permanent & 197(42) & $79(33.1)$ & $91(37.9)$ & $122(25.5)$ & $P(R S, I / C)=<0.001 / 0.003$ \\
\hline Permanent & $51(10.6)$ & $48(20.1)$ & $24(10)$ & $63(13.2)$ & $P(L E / R S ; I)=0.003 / 0.012$ \\
\hline $\begin{array}{l}\text { Number of children }<5 \text { years old in the } \\
\text { household }\end{array}$ & $1(0-2)$ & $1(0-2)$ & $2(1-3)$ & $2(1-3)$ & $P(R S / L E)=1$ and $p(C / I)=1$ \\
\hline \multicolumn{6}{|l|}{ Socio-economic status } \\
\hline Low & 197(41) & $84(35)$ & $180(37.5)$ & 182(37.9) & $p(I / L E)=0.04$ \\
\hline Medium & $180(37.5)$ & $102(42.5)$ & $80(33.3)$ & 233(48.5) & $p(C / R S ; I)=0.03 / 0.001$ \\
\hline High & $103(21.5)$ & $54(22.5)$ & $47(19.6)$ & $65(13.5)$ & $p(R S ; L E / C)=0.007 / 0.01$ \\
\hline \multicolumn{6}{|l|}{ Membership of a local saving association } \\
\hline No & $450(93.8)$ & $135(56.3)$ & $190(79.5)$ & $423(88.1)$ & $p(R S / L E ;, l ; C)=<0.05$ and $p(C / L E ; l)=<0.05$ \\
\hline Yes & $30(6.3)$ & $105(43.8)$ & $49(20.5)$ & $57(11.9)$ & $p(L E / R S ; I ; C)=<0.001$ and $p(I / R S ; C)=<0.05$ \\
\hline
\end{tabular}


"To be upgraded to Characteristics of the population and their distribution in types of health zones In the results"

Data are $n$ (\%) and median (interquartile range).

The bar (/) means that the conditions for applying the test are not met.

For continuous variables, all p-values of the Kruskall-Wallis test were $<0.001$. Therefore, we presented in the table the $p$-value not significant for the tests two by two (Wilcoxson test with Bonferroni correction). For the categorical variables, all the proportions were different on the Chi-square test except for sex. We represent in the table the $p$ value of the $Z$ comparison test of column proportions with Bonferroni correction. Eg: $p(R S / L E)=0.01$ means that the proportion of people "Never married" in accessible stable health zones is statistically higher than the proportion of people "Never married" in remote and stable health zones; but that it is identical to the proportion of people "Never married" in intermediate health zones and in crisis

Table 2

Comparison of the WHODAS score in the health zone types $(n=1440)$

\begin{tabular}{|lllll|}
\hline Items** & $\begin{array}{l}\text { Accessible and } \\
\text { stable (AS) }\end{array}$ & $\begin{array}{l}\text { Remote and } \\
\text { stable (RS) }\end{array}$ & Intermediate & Unstable \\
\hline Household & $0(0-4)$ & $3(1-5)$ & $2(1-4)$ & (U)
\end{tabular}

\section{Factors associated with increased WHODAS score}

Table 3. summarizes the results of the hierarchical linear regression model assessing the independent associations between socio-demographic factors and the type of health zone with the WHODAS score. We chose the second model which had the lower AIC.

In this model, the factors significantly associated with an overall poor health status (or higher WHODAS score) were; advanced age (B = 0.356; $p<0.001)$, being woman $(B=5.776 ; p<0.001)$, being membership of an association $(B=5.944 ; p<0.001)$, being divorced, separated or widower $(B=2.147 ; p=0.003)$ and living in an unstable $\mathrm{HZ}(\mathrm{B}=6.780 ; \mathrm{p}<0.001)$.

Factors significantly associated with an overall higher health status (or lower WHODAS score) were having a permanent housing $(B=-1.838 ; p=0.014)$ and having no formal employment $(-1.334 ; p=0.002)$. 
Table 3

Results of the hierarchic multiple linear regression analysis of WHODAS score $(n=1440)$

\begin{tabular}{|c|c|c|c|c|c|c|}
\hline \multirow[b]{2}{*}{ Variables } & \multicolumn{3}{|l|}{ Modèle 1} & \multicolumn{3}{|l|}{ Modèle 2} \\
\hline & $\begin{array}{l}\text { Unstandardized } \\
\text { coefficients B }\end{array}$ & $\begin{array}{l}\text { Standardized } \\
\text { coefficients B }\end{array}$ & $\mathbf{p}$ & $\begin{array}{l}\text { Unstandardized } \\
\text { coefficients B }\end{array}$ & $\begin{array}{l}\text { Standardized } \\
\text { coefficients B }\end{array}$ & $\mathbf{p}$ \\
\hline Age & 0.377 & 0.290 & $<.001$ & 0.356 & 0.274 & $\hat{0} .001$ \\
\hline Sex & 4.109 & 0.091 & 0.001 & 5.776 & 0.129 & $\hat{0} .001$ \\
\hline Marital statues & 2.053 & 0.074 & 0.01 & 2.147 & 0.077 & 0.003 \\
\hline Respondent's occupation & -2.447 & -0.137 & $<.001$ & -1.334 & -0.075 & 0.002 \\
\hline Membership of an association & 0.939 & 0.068 & 0.006 & 5.944 & 0.100 & $\hat{0} .001$ \\
\hline $\begin{array}{l}\text { Number of children }<5 \text { years old in } \\
\text { the household }\end{array}$ & 0.975 & 0.070 & 0.004 & 0.224 & 0.016 & 0.485 \\
\hline Type of housing & -2.235 & -0.071 & 0.006 & -1.838 & -0.059 & 0.014 \\
\hline Number of adults in the household & -0.910 & -0.085 & 0.001 & -0.348 & -0.033 & 0.163 \\
\hline Socio-economic status & 0.191 & 0.006 & 0.803 & 0.415 & 0.014 & 0.595 \\
\hline Level of crisis of the $\mathrm{HZ}$ & - & - & - & 6.780 & 0.387 & $\hat{0.001}$ \\
\hline $\mathrm{R}^{2}$ & \multicolumn{3}{|l|}{0.177} & \multicolumn{3}{|l|}{0.312} \\
\hline $\mathrm{F}$ & \multicolumn{3}{|l|}{33.497} & \multicolumn{3}{|l|}{63.422} \\
\hline Significance of the model & \multicolumn{3}{|l|}{$<0.001$} & \multicolumn{3}{|l|}{$<0.001$} \\
\hline Variation of $\mathrm{R}^{2}$ & \multicolumn{3}{|l|}{0.177} & \multicolumn{3}{|l|}{0.135} \\
\hline F of the variation of $R^{2}$ & \multicolumn{3}{|l|}{33.497} & \multicolumn{3}{|l|}{273.927} \\
\hline Significance of the variation of $\mathrm{R}^{2}$ & \multicolumn{3}{|l|}{$<0.001$} & \multicolumn{3}{|l|}{$<0.001$} \\
\hline $\mathrm{AlC}^{*}$ & \multicolumn{3}{|l|}{8475.396} & \multicolumn{3}{|l|}{8225.278} \\
\hline \multicolumn{7}{|c|}{$\begin{array}{l}\text { Coding information: Sexe: } 0=\text { Male, } 1=\text { Female ; marital status : } 0=\text { never married, } 1=\text { married, } 2=\text { separated or divorced, } 3=\text { widowed } ; \text { Respondent's } \\
\text { occupation: } 0=\text { formal employee, } 1=\text { part-time employee, } 2=\text { small trader, } 3=\text { cultivator, } 4=\text { unemployed; } \text { Member of saving organization: } 0=\text { No, } 1=\text { Yes; } \\
\text { Housing: } 0=\text { temporary, } 1=\text { semi-permanent, } 2=\text { permanent; Socioeconomic status: } 0=\text { low, } 1=\text { medium, } 2=\text { elevate; Level of crisis: } 0=\text { reachable stable, } 1= \\
\text { reachable landlocked, } 2=\text { Intermediate, } 3=\text { crisis ; *AIC = Akaike information criteria }\end{array}$} \\
\hline
\end{tabular}

\section{Discussion}

Our study found that the overall WHODAS score in our population was high [Med (IQR) = $25(6.3-41.7)]$, mostly in unstable HZs [Med (IQR) = 39.6 (22.9-54.2)] indicating an overall low health status for the population in this area. The RA and IHZs had globally identical scores and more precisely on the items concerning the cognitive and social aspects. The socio-cultural and demographic characteristics of the participants as well as the type of $\mathrm{HZ}$ were associated with the WHODAS score, explaining respectively $17.7 \%$ and $13.5 \%$ of its variance. The factors significantly associated with an overall poor health status (or higher whodas score) were; advanced age, being woman, being membership of an association, being divorced, separated or widower and living in an unstable $\mathrm{HZ}$.

\section{The health status of the population in crisis situations related to the armed conflicts}

In our study, the median WHODAS score in the unstable $\mathrm{HZ}$ was 39.6 , which was significantly higher than in the stable $\mathrm{HZ}(6.3$ and 25,0$)$ or even intermediate (22.9). The median score of UHZ would then be found in the $10 \%$ of the class with severely impaired disability (40). Even if there is no consensus on the cutpoint defining people with an altered health condition from the WHODAS score (40), our results confirm that the populations living in UHZ have a more impaired health status than those living in stable areas.

We note that the deterioration in the health status of the population living in UHZ in South Kivu concerns all six areas of disability, more particularly the cognitive aspects [Med $(\mathrm{IQR})=3(2-5)]$, the execution of daily tasks [Med $(\mathrm{IQR})=4(2-6)]$, mobility [Med $(\mathrm{IQR})=4(2-6)]$ and participation in the social life of the community [Med (IQR) $=4(2-5)]$. Indeed, armed conflicts create a climate of insecurity and impact on the socio-economic and psychological daily lives of people(11, 42). WHODAS 2.0 has proven to be an effective tool for assessing disability caused by post-traumatic stress disorder (43). The chronic crisis related to armed conflicts can be a stressful situation which can lead to a serious physical, psycho-social and mental handicap. The deterioration of cognitive aspects can be justified by the fact that armed conflicts quite often lead to mental disorders (44-46). The prevalence of these disorders is estimated to be around $30 \%$ in the population affected by these conflicts $(44,47)$. People live in fear of being attacked again and no longer go about their daily tasks. 
Unfortunately, most of them, as our study shows (58\%), live on small trade in their local products. The destruction of infrastructure (as well as health structures), the theft of property and physical assault affect emotionally and destroys the community life of the victims.

Our study also showed that aspects related to social life [Med $(I Q R)=1(0-4)]$ and self-care [Med $(I Q R)=1(0-3)]$ were the least affected in a crisis setting. This could be explained by the fact that in crisis settings people are more likely to help each other in order to ensure their survival. Furthermore, the crisis also leads to frequent displacement of populations, pushing people to live in temporary housing, as shown in our results. This nomadic life will expose the population to communicable and rapidly fatal diseases mainly due to the lack of drinking water and a very poor environmental sanitation. (48, 49).

The RS HZ had an overall WHODAS score statistically identical to that of the IHZ. This suggests that isolation during armed conflict could in itself be a factor that can influence the health status of the population. Indeed, it has been noted that populations living in rural and isolated regions are vulnerable in terms of health (50). Vulnerability, which may increase during armed conflicts in neighboring regions, is mainly due to the shortage of healthcare infrastructure and qualified healthcare personnel in these regions (51).

\section{Factors associated with variance in WHODAS score}

Our second hierarchical regression model showed that socio-cultural and demographic factors account for $19 \%$ of the variance in the WHODAS score in our population. The score increases with age $(B=0.356 ; p<0.001)$ and the female sex $(B=5.776 ; p<0.001)$. This corroborates with the results of some authors $(40,52)$. Indeed, it is especially the health status of vulnerable people (women, children, elderly people) which deteriorates during armed conflicts (53-55). This could be linked to the fact that it is women who are most often ill-treated (54), children and elderly people find it difficult to adapt to the nomadic life created by displacement during armed conflict. Also, the latter have a relative immunosuppression that can expose them to communicable diseases which are among the most frequent causes of death during armed conflicts $(56,57)$.

We also note that the WHODAS score decreases in people living in more and more comfortable dwellings $(B=-1.838 ; p=0.014)$. Indeed, having a sustainable and permanent habitat would be a fact which can protect people from environmental and psycho-social risks. It is often people who have not moved in armed conflict who may have these types of accommodation, while IDPs often stay in camps with poorly sanitized permanent accommodation.

Our results also show that the individual's health status improves if he or she does not have a formal job $(B=-1.334 ; p=0.002)$, which is rather curious. Nevertheless, in situations of armed conflict, since it is the psycho-social aspects that are affected, the unemployed may be favored. Indeed, they may have a lot of time to take care of themselves, be more present in their community and may be less stressed by the demands of work.

Our results also suggest that being separated/divorced/widower $(B=2.147 ; p=0.003)$ and being a membership of an association $(B=5.944 ; p<0.001)$ were associated with higher whodas score. These factors can be decisive in the sense that a person's state of health also depends on his relationship with others and the socio-economic climate that prevails around him. The fact that most of the armed conflicts in South Kivu are due to land and tribe issues (58), further alters the socio-economic dynamics of the population living in these conflict zones.

On the other hand, being a member of an association should rather help to better support the crisis situation. Nevertheless, this could be explained by the fact that during periods of conflict, the created associations are dissolved, leading to a setback in the economic life of the person.

This model also showed that the UHZ (crisis areas) explains the variance in the WHODAS score of the population living there at $13.5 \%$. People living in "crisis" health zones had increasingly higher WHODAS scores $(B=6,780 ; p<0.001)$. These results are in line with those of several authors who have found that armed conflicts have a negative impact on the state of health of the population and in several other areas of daily life $(4,55,59,60)$

\section{Strenghts and limitations}

Some limitations of our work are worth discussing. Firstly, concerning the selection of health areas and participants: three health areas initially chosen at random were not visited due to accessibility and insecurity issues. However, they were replaced by three other HA contiguous to the previous ones, better accessible and more secure, which could have the same socio-cultural characteristics. Also, it was more likely that people who went to work could not be found when visiting homes. Thus, we have implemented a double pass system so that all inhabitants have the chance to participate in our study. Second, the fact that the WHODAS tool was not translated into local language (Kibembe, Kitembo, Kirega, Mashi) may affect understanding of the questions. To minimize this, we ensured a good translation of the tool in French and Swahili by a language school according to the principle of translation and counter-transduction advocated by WHO and we pre-tested it. Also, we chose doctors as investigators, guided locally by a community leader. Finally, it is difficult to generalize these results to the entire population (note that we used only 6 on $34 \mathrm{HZs}$ of South Kivu), especially since each community lives in a very specific and very often complex state of crisis. The state of health in this case is the result of several other individual, socio-cultural and environmental parameters which are difficult to grasp. However, our study shows that living in a crisis $\mathrm{HZ}$ is an important factor contributing to the deterioration of people's health.

Our study nevertheless presents some strengths. It is among the first to study the state of health of the general population in areas affected by crises related to armed conflicts in South Kivu. This is particular, especially since in most cases, the health status of the population is assessed through disease-based or heath programs indicators for the management of these diseases. WHODAS allowed us to see the state of the population's health from a broader perspective, linked to development capacity. This could guide policy makers to have a second view of the real health status of the population, especially those in regions of chronic crisis.

\section{Conclusions}


The crisis related to armed conflicts is a factor which impacts on persons' health status in several dimensions of their daily life. The assessment of health status of the population in this situation must consider the daily life of the person. The measures usually used, such as those of morbidity and mortality, do not allow a good understanding of the state of health of the person under these conditions. The WHODAS score turns out to be a more suitable tool for these purposes. People living in remote health zones appear to have similar health conditions than those living in intermediate health zones; that suggests that isolation can be a factor which can compromise people's health in conflict settings.

\section{Abbreviations}

AIC: Akaike information criteria

ASHZ: Accessible and stable Health Zone

BRD: Battle-related Deaths

DRC: Democratic Republic of Congo

HZ: Health Zone

IDPs: Internally Displaced Persons

IHZ: Intermediate Health Zone

Med (IQR): Median (Interquartile Range)

QGIS: Quantum Geographic Information System

RSHZ: Remote and Stable Health Zone

UCDP BRD: Uppsala Conflict Data Program Battle-related Deaths Dataset

UHZ: Unstable Health Zone

UNOCHA: United Nations Office for the Coordination of Humanitarian Affairs

WHODAS: World Health Organization Disability Assessment Schedule

\section{Declarations}

\section{Ethics approval and consent to participate}

Authorization from the ethics committees of the Catholic University of Bukavu was obtained for this study. Verbal consent was obtained from people who expressed their willingness to participate in this study.

\section{Consent for publication}

Not applicable

\section{Availability of data and materials}

The datasets used and/or analyzed during the current study are available from the corresponding author on reasonable request

\section{Competing interests}

The authors declare that they have no competing interests

\section{Funding}

This study is part of a synergy project involving the PRD (Projet de Recherche pour le développement), financed by ARES, and RIPSEC RDC (Renforcement Institutionnel des Politiques de Santé basées sur l'Evidence en République Démocratique du Congo)

\section{Authors' contributions}

SML substantially contributed to study design, data collection, gave significant input to data analyzation and discussion, significantly contributed to the manuscript writing and revision

EBM substantially contributed to study design, data collection, gave significant input to data discussion, contributed to the manuscript revision

ASL substantially contributed to data analyzation and contributed to the manuscript revision

HK substantially contributed to study design and the manuscript revision 
CM substantially contributed to the manuscript revision

AT significantly contributed to the manuscript revision

SBS significantly contributed to the manuscript revision

GB substantially contributed to study design, data collection, gave significant input to data discussion, contributed to the manuscript writing and revision

PD substantially contributed to the manuscript revision

JM substantially contributed to study design, data collection, gave significant input to data discussion, contributed to the manuscript writing and revision

All authors read and approved the final manuscript

\section{Acknowledgements}

Not applicable

\section{References}

1. OECD. States of Fragility 2018 [Internet]. States of Fragility 2018. Paris: OECD Publishing; 2018 [cited 2019 Oct 28]. Available from: https://doi.org/10.1787/9789264302075-en

2. Thompson R, Kapila M. Healthcare in Conflict Settings: Leaving No One Behind. 2018.

3. Namasivayam A, Arcos González P, Castro Delgado R, Chi PC. The Effect of Armed Conflict on the Utilization of Maternal Health Services in Uganda: A Population-based Study. PLoS Curr [Internet]. 2017 Oct 3 [cited 2019 Oct 28];9. Available from: http://www.ncbi.nlm.nih.gov/pubmed/29188138

4. Alice D. Providing Healthcare in Armed Conflict: The Case of Mali [Internet]. 2019 [cited 2019 Oct 28]. Available from: www.ipinst.org

5. Franco S, Suarez CM, Naranjo CB, Báez LC, Rozo P. The effects of the armed conflict on the life and health in Colombia. Vol. 11, Ciencia e Saude Coletiva. Associacao Brasileira de Pos - Graduacao em Saude Coletiva; 2006. p. 349-61.

6. Ghobarah HA, Huth P, Russett B. Civil wars kill and maim people - Long after the shooting stops. Vol. 97, American Political Science Review. 2003. p. 189202.

7. Collier P. On the economic consequences of civil war. Oxf Econ Pap. 1999 Jan 1;51(1):168-83.

8. Kang SJ, Sawada Y, Chung YW. Long-term consequences of armed conflicts on poverty: the case of Cambodia. Asia-Pacific J Reg Sci. 2017 Oct;1(2):519-35.

9. Lai B, Thyne C. The effect of civil war on education, 1980-97. J Peace Res. 2007 May;44(3):277-92.

10. Guha-Sapir D, Panhuis VW. Armed Conflict and Public Health: A report on knowledge and knowledge gaps [Internet]. 2002 [cited 2019 Oct 28 ]. Available from: https://reliefweb.int/report/world/armed-conflict-and-public-health-report-knowledge-and-knowledge-gaps

11. Gates S, Hegre H, Nygård HM, Strand H. Development Consequences of Armed Conflict. World Dev. 2012 Sep;40(9):1713-22.

12. Thomas de SM. Case Study, Armed Conflicts in the Great Lakes Region (1994-2005) [Internet]. 2019 [cited 2019 Oct 28]. Available from: https://casebook.icrc.org/case-study/case-study-armed-conflicts-great-lakes-region-1994-2005

13. Center of Disease Control and Prevention. Elevated mortality associated with armed conflict - Democratic Republic of Congo, 2002 [Internet]. Vol. 52 , Morbidity and Mortality Weekly Report. 2003 [cited 2019 Oct 28]. p. 469-71. Available from:

https://www.cdc.gov/mmwr/preview/mmwrhtml/mm5220a3.htm

14. Ministère de la Santé. RDC. Plan National de Développement Sanitaire recadré pour la période 2019-2022: Vers la couverture sanitaire universelle. Kinshasa; 2018.

15. Stearns JK, Vogel C. The Landscape of Armed Groups in the Eastern Congo. Kivu Secur Tracker [Internet]. 2015 [cited 2019 Oct 28 ];(December):1-10. Available from: https://www.researchgate.net/publication/318265117_The_Landscape_of_Armed_Groups_in_the_Eastern_Congo

16. Human Rights Watch. World Report 2019: Democratic Republic of Congo [Internet]. 2018 [cited 2019 Oct 10]. Available from: https://www.hrw.org/worldreport/2019/country-chapters/democratic-republic-congo

17. Kivu Security Tracker. Dans les Kivus, l'insécurité des soignants s'aggrave [Internet]. 2019 [cited 2019 Oct 10]. Available from: https://blog.kivusecurity.org/fr/dans-les-kivus-linsecurite-des-soignants-saggrave

18. UNOCHA. RD Congo - Sud-Kivu et Maniema: Note d'informations humanitaires du 26.06.2018 [Internet].2018[cited20190ct28].Available from :https://www.humanitarianresponse.info/sites/www.humanitarianresponse.info/files/documents/files/ocha_sudkivu_maniema_note_informations_huma

19. Porignon D. Porignon D. Adéquation des systèmes de santé de district en situation critique: expériences dans la région des Grands Lacs africains. Université Catholique de Louvain; 2003.

20. UNOCHA. South Kivu: A spiralling humanitarian crisis [Internet]. 2018 [cited 2019 Oct 28]. Available from: https://www.unocha.org/story/south-kivuspiralling-humanitarian-crisis

21. USAID. Democratic Republic of the Congo: Nutrition Profile. 2018.

22. Ministère de la santé Publique. RDC. Deuxième enquête démographique et de santé (EDS-RDC II 2013-2014). Kinshasa; 2014.

23. Ministère de la santé Publique. RDC. SNIS: Catalogue des indicateurs. Kinshasa; 2004.

Page 10/12 
24. Malembaka EB, Karemere H, Balaluka GB, Lambert AS, Muneza F, Deconinck H, et al. A new look at population health through the lenses of cognitive, functional and social disability clustering in eastern DR Congo: a community-based cross-sectional study. BMC Public Health. 2019 Jan 21;19(1).

25. INS. Annuaire Statistique 2015. Kinshasa: Ministère du Plan, RDC; 2017.

26. Department of Peace and Conflict. Uppsala University. Uppsala Conflict Data Program [Internet]. 2018 [cited 2019 Sep 23]. Available from: https://ucdp.uu.se/

27. Pettersson T, Högbladh S, Öberg M. Organized violence, 1989-2018 and peace agreements. J Peace Res [Internet]. 2019 Jul 3 [cited 2019 Sep 23];56(4):589-603. Available from: http://journals.sagepub.com/doi/10.1177/0022343319856046

28. Petterson T. UCDP Battle-related Deaths Dataset Codebook v 19.1. In 2019. Available from: https://ucdp.uu.se/downloads/

29. Wagner Z, Heft-Neal S, Bhutta ZA, Black RE, Burke M, Bendavid E. Armed conflict and child mortality in Africa: a geospatial analysis. Lancet [Internet]. 2018 Sep 8 [cited 2019 Sep 23];392(10150):857-65.Availablefrom: https://www.sciencedirect.com/science/article/pii/S0140673618314375?via\%3Dihub

30. Sundberg R, Eck K, Kreutz J. Introducing the UCDP Non-State Conflict Dataset. J Peace Res [Internet].2012Mar11[cited2019Sep23];49(2):35162.Availablefrom: http://journals.sagepub.com/doi/10.1177/0022343311431598

31. UNOCHA. DRCongo Healy Zones [Internet]. 2019 [cited 2019 Sep 23]. Available from: https://data.humdata.org/organization/ocha-dr-congo

32. Boerma T, Tappis H, Saad-Haddad G, Das J, Melesse DY, DeJong J, et al. Armed conflicts and national trends in reproductive, maternal, newborn and child health in sub-Saharan Africa: what can national health surveys tell us? BMJ Glob Heal [Internet]. 2019 [cited 2019 Oct 29];4(Suppl 4):e001300. Available from: http://www.ncbi.nlm.nih.gov/pubmed/31297253

33. UNOCHA. Democratic Republic of Congo: Internally Displaced People and returnees (March 2014) [Internet].2014[cited2019Sep30].Availablefrom:https://reliefweb.int/report/democratic-republic-congo/democratic-republic-congo-internally-displacedpeople-and-returne-2

34. UNOCHA. Democratic Republic of Congo: Internally Displaced Persons and Returnees (as of 31 December 2017) [Internet]. 2018 [cited 2019 Sep 30] Available from: https://reliefweb.int/report/democratic-republic-congo/democratic-republic-congo-internally-displaced-persons-and-4

35. OCHA. Guiging principles on international displacement [Internet]. 1998 [cited 2019 Sep 30]. Availablefrom:http://www.internaldisplacement.org/sites/default/files/publications/documents/199808-training-OCHA-guiding-principles-Eng2.pdf

36. Federici S, Bracalenti M, Meloni F, Luciano J V. World Health Organization disability assessment schedule 2.0: An international systematic review. Vol. 39, Disability and Rehabilitation. Taylorand Francis Ltd; 2017. p. 2347-80.

37. Saltychev M, Katajapuu N, Bärlund E, Laimi K. Psychometric properties of 12-item self-administered World Health Organization disability assessment schedule 2.0 (WHODAS 2.0) among general population and people with non-acute physical causes of disability - systematic review. Disabil Rehabil. 2019 Jul 23;1-6.

38. Rehm J, Üstün TB, Saxena S, Nelson CB, Chatter S, Ivis F, et al. On the development and psychometric testing of the WHO screening instrument to assess disablement in the general population. Int J Methods Psychiatr Res [Internet]. 1999 Jun 1 [cited 2019 Oct 16];8(2):110-22. Available from: http://doi.wiley.com/10.1002/mpr.61

39. Scorza P, Stevenson A, Canino G, Mushashi C, Kanyanganzi F, Munyanah M, et al. Validation of the "World Health Organization Disability Assessment Schedule for Children, WHODAS-Child" in Rwanda. PLoS One [Internet]. 2013 [cited 2019 Oct 28];8(3):e57725. Available from: http://www.ncbi.nlm.nih.gov/pubmed/23505437

40. Andrews G, Kemp A, Sunderland M, von Korff M, Ustun TB. Normative data for the 12 item WHO disability assessment schedule 2.0. Ross JS, editor. PLoS One [Internet]. 2009 Dec 17 [cited 2019 Oct 16];4(12):e8343. Available from: https://dx.plos.org/10.1371/journal.pone.0008343

41. Filmer D, Pritchett LH. Estimating wealth effects without expenditure data - Or tears: An application to educational enrollments in states of India. Demography [Internet]. 2001 Feb [cited20190ct28];38(1):115-32.Availablefrom: http://www.jstor.org/stable/3088292?origin=crossref

42. Ghobarah HA, Huth P, Russett B. The post-war public health effects of civil conflict. Soc Sci Med. 2004 Aug;59(4):869-84.

43. Marx BP, Wolf EJ, Cornette MM, Schnurr PP, Rosen MI, Friedman MJ, et al. Using the WHODAS 2.0 to assess functioning among veterans seeking compensation for posttraumatic stress disorder. Psychiatr Serv. 2015 Dec 1;66(12):1312-7.

44. Weisleder P, Rublee C. The Neuropsychological Consequences of Armed Conflicts and Torture. Vol. 18, Current Neurology and Neuroscience Reports. Current Medicine Group LLC 1; 2018.

45. Jaung M, Jani S, Banu S, Mackey JM. International Emergency Psychiatry Challenges: Disaster Medicine, War, Human Trafficking, Displaced Persons. Vol. 40, Psychiatric Clinics of North America. W.B. Saunders; 2017. p. 565-74.

46. Patel V, Chisholm D, Parikh R, Charlson FJ, Degenhardt L, Dua T, et al. Addressing the burden of mental, neurological, and substance use disorders: Key messages from Disease Control Priorities, 3rd edition. Vol. 387, The Lancet. Lancet Publishing Group; 2016. p. $1672-85$.

47. Bogic M, Njoku A, Priebe S. Long-term mental health of war-refugees: a systematic literature review. BMC Int Health Hum Rights. 2015 Oct 28;15(1).

48. Murray CJL, King G, Lopez AD, Tomijima N, Krug EG. Armed conflict as a public health problem. Vol. 324, British Medical Journal. 2002 . p. 346-9.

49. Li Q, Wen M. The immediate and lingering effects of armed conflict on adult mortality: A time-series cross-national analysis [Internet]. Vol. 42, Journal of Peace Research. 2005 [cited 2019 Nov8].p.471-92.Availablefrom:http://journals.sagepub.com/doi/10.1177/0022343305054092

50. Goodridge D, Marciniuk D. Rural and remote care. Vol. 13, Chronic Respiratory Disease. SAGE Publications Ltd; 2016. p. $192-203$.

51. Oosterveer TM, Young TK. Primary health care accessibility challenges in remote indigenous communities in Canada's North. Int $\mathrm{J}$ Circumpolar Health. 2015;74:1-7. 
52. Ferrer MLP, Perracini MR, Rebustini F, Buchalla CM. WHODAS 2.0-BO: Normative data for the assessment of disability in older adults. Rev Saude Publica. 2019;53(1).

53. Wagner Z, Heft-Neal S, Wise PH, Black RE, Burke M, Boerma T, et al. Women and children living in areas of armed conflict in Africa: a geospatial analysis of mortality and orphanhood. Lancet Glob Heal [Internet]. 2019 Oct 24 [cited 2019 Nov 11]; Available from: http://www.ncbi.nlm.nih.gov/pubmed/31669039

54. Plümper, T; Neumayer E. The Unequal Burden of War: The Effect of Armed Conflict on the Gender Gap in Life Expectancy. Int Organ [Internet]. 2006;60(3):723-54. Available from: http://www.jstor.org/stable/3877825

55. Murray CJL, King G, Lopez AD, Tomijima N, Krug EG. Armed conflict as a public health problem [Internet]. Vol. 324, British Medical Journal. BMJ Publishing Group; 2002 [cited 2019 Sep 23]. p. 346-9. Available from: http://www.ncbi.nlm.nih.gov/pubmed/11834565

56. Levy BS, Sidel VW. Documenting the Effects of Armed Conflict on Population Health. Annu Rev Public Health [Internet]. 2016 Mar 18 [cited 2019 Nov 11];37(1):205-18. Available from: http://www.annualreviews.org/doi/10.1146/annurev-publhealth-032315-021913

57. Kerridge BT, Khan MR, Rehm J, Sapkota A. Conflict and diarrheal and related diseases: A global analysis. J Epidemiol Glob Health. 2013 Dec;3(4):269-77.

58. International Alert. Beyond Stabilisation: Understanding the Conflict Dynamics in North and South Kivu, Democratic Republic of Congo [Internet]. 2015 [cited 2019 Nov 11]. Available from: www.international-alert.org

59. Spiegel PB, Checchi F, Colombo S, Paik E. Health-care needs of people affected by conflict: future trends and changing frameworks [Internet]. Vol. 375, The Lancet. 2010 [cited 2019 Nov 11].p.341-5. Available from: https://linkinghub.elsevier.com/retrieve/pii/S0140673609618730

60. Sidel VW, Levy BS. The health impact of war. Int J Inj Contr Saf Promot. 2008;15(4):189-95. 